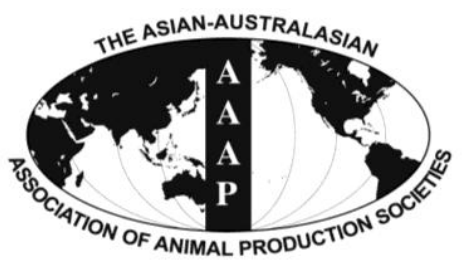

Asian Australas. J. Anim. Sci.

Vol. 26, No. 8 : 1089-1101 August 2013

http://dx.doi.org/10.5713/ajas.2012.12712

www.ajas.info

pISSN 1011-2367 elSSN 1976-5517

\title{
Effect of Varying the Energy Density of Protein-adequate Diets on Nutrient Metabolism, Clinical Chemistry, Immune Response and Growth of Muzaffarnagari Lambs
}

\author{
V. K. Singh, A. K. Pattanaik*, T. K. Goswami ${ }^{1}$, and K. Sharma \\ Centre of Advanced Studies in Animal Nutrition, Indian Veterinary Research Institute, Izatnagar, India
}

\begin{abstract}
Effects of varied dietary energy densities on immune response and performance of Muzzafarnagari lambs were ascertained in a 180-d study. Animals ( $\mathrm{n}=24)$, in three groups, were fed diets providing $100 \%(100 \mathrm{E}), 80 \%(80 \mathrm{E})$ or $70 \%(70 \mathrm{E})$ of their metabolizable energy requirement. Mean nutrient digestibilities varied significantly among treatments. Nitrogen intake was lower $(\mathrm{p}<$ $0.01)$ in the 70E. Nitrogen retention, was reduced $(\mathrm{p}<0.001)$ in $80 \mathrm{E}$ and $70 \mathrm{E}$ vs $100 \mathrm{E}$. The average daily gain $(\mathrm{p}<0.001)$ was $47.01 \pm$ $4.23,13.54 \pm 1.72$ and $-16.67 \pm 8.24 \mathrm{~g}$ for $100 \mathrm{E}, 80 \mathrm{E}$ and $70 \mathrm{E}$, respectively. Hemoglobin concentration, haematocrit, total and differential leukocyte counts were lower $(\mathrm{p}<0.001)$ for $80 \mathrm{E}$ and $70 \mathrm{E}$ than for $100 \mathrm{E}$ with a similar trend $(\mathrm{p}<0.05)$ for serum glucose and total protein. Serum cortisol was reduced $(\mathrm{p}<0.001)$ with decreased energy availability. Antibody titre to Brucella abortus S19 showed an initial reduction in $80 \mathrm{E}$ and $70 \mathrm{E}$ vs $100 \mathrm{E}$. Delayed-type hypersensitivity response was lower $(\mathrm{p}<0.001)$ in $80 \mathrm{E}$ and $70 \mathrm{E}$ vs $100 \mathrm{E}$, accompanying a lower $(\mathrm{p}<0.001)$ nitric oxide production by the peripheral lymphocytes. It is concluded that the reduced dietary energy density significantly affects the growth performance and immune response of lambs. (Key Words: Clinical Chemistry, Cortisol, Energy, Immunity, Nutrient Utilization, Lambs)
\end{abstract}

\section{INTRODUCTION}

Feed resources and nutrition constitute the principal constraints to ruminant production in Asia (Devendra and Sevilla, 2002). Increasing population of small ruminants, increasing desertification, together with a fall in total feed resources due to overgrazing, ploughing of marginal land and soil erosion, have led to a situation wherein goats and sheep are facing serious nutrient shortages (Ben Salem and Smith, 2008). A perpetual gap between demand and supply of energy and protein (Singh et al., 1997) has been identified with the extensive system of ruminant production in most of the tropics including India. In these countries, underfeeding can be of high magnitude (Doreau et al., 2003). This is especially true in case of small ruminants with a gradual shrinking of rangeland reserves and diversion of high quality feed ingredients for high

\footnotetext{
* Corresponding Author: Ashok Kumar Pattanaik. Tel: +91-581230-1318, Fax: +91-581-230-1318, E-mail: akpattanaik1@gmail. com

${ }^{1}$ Immunology Section, Indian Veterinary Research Institute, Izatnagar, India.

Submitted Dec. 23, 2012; Accepted Feb. 15, 2013; Revised Mar. 12, 2013
}

producing dairy animals. Eventually, small ruminants across the tropics are prone to periodic deficiency of macro- as well as micro- nutrients.

In addition to the above, periodic energy deficiencies are also quite prevalent under intensive systems of animal production, for example, during the periparturient stages of life in ruminants. In fact, it is an important factor in the development of such well known disorders as ketosis and fatty liver syndrome in dairy cows or pregnancy toxemia in ewes (Gaal et al., 1993).

Ruminants are able to cope with underfeeding by mobilisation of body reserves, even when the level of restriction is very high, as shown in fat-tail ewes (Atti and Bocquier, 1999). However, the metabolic adaptations may vary with the extent and type of malnutrition and, more importantly, with the physiological state of the animal. Further, the metabolic adjustments in terms of immune related mechanism are still not properly elucidated, particularly in growing animals. Immune functions have traditionally been regarded as part of maintenance requirements, but an increasing body of evidence suggests the sensitivity of immunity to nutrient supply (Galyean et al., 1999). We have recently reported that a dietary protein 
deprivation induced a decline in cell-mediated and humoral immune response in sheep accompanying alterations in related metabolic profile (Sahoo et al., 2009). However, only a few studies have examined the relationship between energy balance and immune system function in ruminants (Moyes et al., 2009). With most of these studies having focused on periparturient energy availability, the relation between energy status and immunity of growing ruminants is generally lacking, especially in terms of long-term studies.

In this backdrop, the present study was undertaken with an objective of assessing the influence of varied dietary energy densities of a protein-adequate diet on immune response of growing Muzaffarnagari lambs besides nutritional performance and clinical chemistry indices.

\section{MATERIALS AND METHODS}

\section{Animals and management}

The experimental procedures were in accordance with the ethical protocol and approved by the Staff Research Council and Institute Animal Ethics Committee of the institute. Twenty-four male and female Muzzafarnagari lambs, 6 to 9 months of age and $26.56 \pm 2.04 \mathrm{~kg} \mathrm{BW}$, were divided into three equal groups namely, normal energy $(100 \mathrm{E})$, medium energy (80E) and low energy (70E). The animals were housed in a well maintained concrete floored barn with provision for individual feeding. There were facilities for exercise and drinking water in the adjacent open paddocks, where the animals were let loose for $2 \mathrm{~h}$ each day in the morning. Before the study, the animals were fed a standard diet consisting of concentrate supplement and wheat straw for over two weeks, and the voluntary feed (DM) intake was determined as $25 \mathrm{~g} / \mathrm{kg} \mathrm{LW}$. Prior to that, the animals were dewormed with the anthemintic albendazole (Albomar, $5 \mathrm{mg} / \mathrm{kg}$ BW; Glaxo Smith Kline Pharmaceuticals Limited, Mumbai, India). All the animals were maintained under strict hygienic and uniformed management during the 180-d experiment. Body weight was determined every 2 wks.

\section{Feeds and feeding}

The animals of $100 \mathrm{E}, 80 \mathrm{E}$ and $70 \mathrm{E}$ groups were fed at 100, 80 and 70 percent of the metabolizable energy (ME) requirement, respectively, as per Kearl (1982). The ME content of the diets in $80 \mathrm{E}$ and $70 \mathrm{E}$ groups was reduced by 20 and 30 percent (on as-fed basis) of that in 100E through qualitative and quantitative alterations in the diet composition. Accordingly, the assumed ME requirement for maintenance and $50 \mathrm{~g}$ daily growth $(1.56 \mathrm{Mcal} / \mathrm{d})$ in the $100 \mathrm{E}$ group was reduced to 1.27 and $1.12 \mathrm{Mcal} / \mathrm{d}$ for $80 \mathrm{E}$ and $70 \mathrm{E}$, respectively. The protein content of diets for the restricted groups was increased (by manipulating the levels of maize and soybean meal in the concentrate) to equalize daily intake of crude protein across the three groups (Table 1). The lambs were offered calculated amount of the respective concentrate supplements, with a basal diet of wheat straw. The desired variation in energy intake was achieved by varying the concentrate: roughage ratio of the $100 \mathrm{E}, 80 \mathrm{E}$ and $70 \mathrm{E}$ diets at $0.40,0.20$ and 0.10 , respectively. The quantity of wheat straw fed to individual animals was

Table 1. Ingredient and chemical composition of experimental feeds

\begin{tabular}{|c|c|c|c|c|}
\hline \multirow{2}{*}{ Component } & \multicolumn{3}{|c|}{ Concentrate supplement $^{1}$} & \multirow{2}{*}{ Wheat straw } \\
\hline & $100 \mathrm{E}$ & $80 \mathrm{E}$ & $70 \mathrm{E}$ & \\
\hline \multicolumn{5}{|c|}{ Ingredient composition ( $\mathrm{g} / \mathrm{kg}$ air dry basis) } \\
\hline Maize & 830 & 520 & 0 & - \\
\hline Soybean meal & 150 & 460 & 980 & - \\
\hline Mineral mixture $^{2}$ & 15 & 15 & 15 & - \\
\hline Common salt & 5 & 5 & 5 & - \\
\hline \multicolumn{5}{|c|}{ Chemical composition (g/kg DM basis) } \\
\hline $\mathrm{OM}$ & 941.6 & 910.0 & 906.7 & 915.0 \\
\hline $\mathrm{CP}$ & 158.8 & 285.0 & 479.4 & 48.5 \\
\hline Ether extract & 32.2 & 24.4 & 20.2 & 10.8 \\
\hline Total carbohydrates ${ }^{3}$ & 750.6 & 600.6 & 407.1 & 856.0 \\
\hline Total ash & 58.4 & 90.0 & 93.3 & 81.5 \\
\hline NDF & 368.1 & 315.4 & 324.9 & 825.3 \\
\hline $\mathrm{ADF}$ & 57.0 & 99.7 & 103.9 & 482.4 \\
\hline Hemicellulose & 311.1 & 215.7 & 221.0 & 338.5 \\
\hline $\mathrm{ME}(\mathrm{Mcal} / \mathrm{kg})^{4}$ & 3.25 & 3.12 & 2.88 & 1.34 \\
\hline
\end{tabular}

$100 \mathrm{E}, 80 \mathrm{E}$ and $70 \mathrm{E}$ diets were designed to supply 100,80 and 70\%, respectively, of energy requirements.

${ }^{1}$ Added $20 \mathrm{~g}$ vitablend $\mathrm{AD}_{3} / 100 \mathrm{~kg}$ concentrate mixture which contained vitamin $\mathrm{A} 50,000 \mathrm{IU}$ and $\mathrm{D}_{3}$ 5,000 IU per gram.

${ }^{2}$ Contained per kilogram: $280 \mathrm{~g}$ of $\mathrm{Ca} ; 120 \mathrm{~g}$ of P; $5 \mathrm{~g}$ of Fe; $0.26 \mathrm{~g}$ of $\mathrm{I} ; 0.77 \mathrm{~g}$ of $\mathrm{Cu} ; 0.13 \mathrm{~g}$ of Co.

${ }^{3}$ Calculated as: $\mathrm{OM}-(\mathrm{CP}+$ ether extract $) . \mathrm{NDF}=\mathrm{Neutral}$ detergent fibre; $\mathrm{ADF}=$ Acid detergent fibre.

${ }^{4}$ Calculated using standard table values. 
calculated to achieve a near ad libitum total DM intake at $25 \mathrm{~g} / \mathrm{kg} \mathrm{BW}$ to prevent possibly compensatory intake of wheat straw by $80 \mathrm{E}$ and $70 \mathrm{E}$. Concentrate supplement was offered on an individual animal basis at $09.00 \mathrm{~h}$ after recording the residues, if any. Wheat straw was offered after ensuring complete consumption of the concentrates. The animals had access to clean drinking water twice a day (30 min each) during morning and afternoon hours.

\section{Metabolism trial}

Following $90 \mathrm{~d}$ of feeding, a metabolism trial involving quantitative determination of intake and output of nutrients was conducted after allowing the animals a 4-d adaptation period. During the collection period of $6 \mathrm{~d}$, amounts of feeds offered, residues left, and faeces and urine excreted were recorded each day. Daily samples of concentrate, wheat straw, residues and faeces voided were kept for DM estimation. The samples of faeces and feeds were dried at $60^{\circ} \mathrm{C}$ in a forced-draft oven, ground through a $2 \mathrm{~mm}$ screen in a laboratory mill (SM100, Retsch GmbH, Stadt Haan, Germany) and stored in airtight high-density polyethylene jars pending further analysis. A further aliquot (0.1) of fresh faeces was mixed with $10 \mathrm{ml}$ of 1:4 sulfuric acid and preserved in airtight bottles for $\mathrm{N}$ determination. Similarly, an aliquot $(0.5 \mathrm{v} / \mathrm{v})$ of urine was taken into the Kjeldahl flask containing $50 \mathrm{ml}$ sulfuric acid for later analysis and qualification of nitrogen.

\section{Blood collection and analysis}

Blood was collected from the lambs by jugular venipuncture at $0,60,120$ and $180 \mathrm{~d}$ in two sets of sterile glass tubes, one with the anticoagulant, ethylene diamine tetra acetate (EDTA, $1 \mathrm{mg} / \mathrm{ml}$ of blood) for hematological analysis. The second set of blood, collected without anticoagulant, was centrifuged at $1,000 \times g$ for $20 \mathrm{~min}$ to harvest serum. Serum samples were stored at $-20^{\circ} \mathrm{C}$ for blood biochemical analysis.

The hemoglobin $(\mathrm{Hb})$ concentration and packed-cell volume (PCV) were assessed according to the methods described by Richterich (1969) and Jain (1986), respectively. Total and differential leukocyte counts (TLC and DLC) were performed by adopting the methods laid down by Schalm et al. (1975). Analyses of the serum samples for glucose, total proteins, albumin and globulin were performed using commercial kits (Span Diagnostics Private Limited, Surat, India). Serum cortisol was estimated by radio-immuno assay using a Multi Crystal Gamma Counter (LB 2103, Berthold-Wallac, Wildbad, Germany) as per Tunn et al. (1992), using commercial kits manufactured and supplied by Immunotech (Marseille, France).

\section{Immune response assessment}

The immune status of the animals was appraised towards the end of the experiment by assessing both humoral and cell mediated immune responses. The humoral immunity of lambs was assessed following160 days using heat killed Brucella aborts S19 soluble antigen as an immunogen. Before inoculation of the B. abortus antigen, all the lambs were screened for the presence of prior antibody against Brucella using Rose Bengal Plate Test (RBPT), as per the procedure of Alton et al. (1975). The blood was collected from the lambs at $0,7,14$ and $21 \mathrm{~d}$ of post-inoculation in clean sterile glass tubes and the separated serum samples stored in sterile vials at $-20^{\circ} \mathrm{C}$ for measuring the antibody titre by enzyme-linked immnosorbent assay (ELISA) as described by Salih-Alj Debbarh et al. (1996). A constant dilution (1:1,000 in phosphate buffer saline with Tween-20) of serum for each test serum was used for antigen-antibody reaction and the colour developed was measured at $492 \mathrm{~nm}$ using UV-Vis spectrophotometer (UV 2800, Labomed Inc., Culver City, CA, USA). Absorbance related directly to the amount of antibody present.

The cell mediated immune (CMI) response was assessed through in vivo delayed type hypersensitivity (DTH) reaction against phytohaemagglutinine-P (PHA-P) as well as in vitro nitric oxide production by lymphocytes. The DTH response was assessed following 150 days as described elsewhere (Pattanaik et al., 2007).

Production of nitric oxide (NO), both constitutive (basal) and inducible (following stimulation), by activated macrophages is recognized a potent immune activation mechanism. NO, a highly labile gaseous free radical is rapidly oxidized to nitrite. The amount of nitrite within culture supernatant is indicative of the amount of $\mathrm{NO}$ produced by cells in culture (Waters et al., 2002). In vitro nitrite production, both constitutive (basal) and inducible (after stimulation with lipopolysachharides; LPS), by lymphocytes in the culture medium was determined by the Griess's reaction method (Green et al., 1982). Whole blood was collected into heparinized tubes by jugular venipuncture from each animal. The blood was diluted 1:1 with Hank's balanced salt solution (HBSS) and $7 \mathrm{ml}$ of the blood/HBSS mixture was layered over $4 \mathrm{ml}$ of histopaque (Sigma-Aldrich Co., St. Louis, MO, USA). Briefly, mononuclear cells (PBMC) from the peripheral blood were separated by density gradient centrifugation (Boyum, 1968). Cell concentration was adjusted to $5 \times 10^{6}$ cell $/ \mathrm{ml}$ in RPMI1640 medium (phenol free) having $10 \%$ fetal calf serum, $100 \mathrm{IU}$ penicillin, $100 \mu \mathrm{g}$ streptomycin and supplemented with $5 \mathrm{mM}$ L-arginine. Ninety-six-well flat-bottomed tissue culture plate wells were seeded with $5 \times 10^{6}$ cells in $100 \mu \mathrm{l}$ volume of above medium followed by incubation at $37^{\circ} \mathrm{C}$ under $5 \% \mathrm{CO}_{2}$ for $48 \mathrm{~h}$. For the estimation of nitric oxide, culture supernatant $(50 \mu \mathrm{l})$ was mixed with an equal volume of Griess reagent [0.1\% N-(1-naphthyl) ethylenediamine 
dihydrochloride, $1 \%$ sulfanilamide and $\left.2.5 \% \mathrm{H}_{3} \mathrm{PO}_{4}\right]$ and absorbance was recorded at $570 \mathrm{~nm}$ using a micro plate reader (Microscan-MS5605A, Electronic Corporation of India Limited, Hyderabad, India). Nitrite level was determined by comparison with a sodium nitrite standard curve.

\section{Feed analyses and statistics}

Sample of feedstuffs, feed refusals, and faeces were analyzed for DM by oven drying method at $100^{\circ} \mathrm{C}(934.01)$, OM by muffle furnace incineration (967.05), EE by Soxhlet extraction (920.39), $\mathrm{N}$ by Kjeldahl method (984.13), CP $(\mathrm{N} \times 6.25)$ and ash (942.05) following the procedures of AOAC (1995). Total carbohydrates were determined by subtracting from OM, the sum of $\mathrm{CP}$ and EE. The OMD \% was converted to digestible organic matter in the DM (DOMD \%) using the equation DOMD \% = OMD \%×(100ash\%)/100; ME value (MJ/kg DM) was then calculated as $\mathrm{ME}(\mathrm{MJ} / \mathrm{kg} \mathrm{DM})=0.15 \times \mathrm{DOMD} \%$ (MAFF, 1984). Fibre fractions viz. NDF and ADF were estimated by the methods of Van Soest et al. (1991); NDF was assayed with sodium sulfite and $\alpha$-amylase in the NDF reagent. Both NDF and ADF were expressed with residual ash.

Statistical analysis of the data was performed using PASW 17.0 statistical package. Intake, digestibility and nitrogen balance data were analysed by 2-way ANOVA, with energy levels and sex as factors. Data on live weight changes and blood parameters were analysed by means of ANOVA for repeated-measures procedure. Because sex did not influence any of these parameters, the analysis included between-subject main effect of energy level, within-subject main effect of day of sampling and interaction day of sampling $\times$ energy level. Significance was declared at $\mathrm{p}<0.05$; differences among means were tested using least significant difference. All statistical procedures were carried out as per Snedecor and Cochran (1989).

\section{RESULTS AND DISCUSSION}

\section{Nutrient intake and utilization}

The results of intake and digestibility of nutrients are presented in Table 2 along with the nutritive value of the

Table 2. Intake and digestibility of nutrients by lambs fed varied levels of dietary energy

\begin{tabular}{|c|c|c|c|c|c|c|c|}
\hline \multirow{2}{*}{ Parameter } & \multicolumn{3}{|c|}{ Dietary groups } & \multirow{2}{*}{ SEM } & \multicolumn{3}{|c|}{ Significance $^{1}$} \\
\hline & $100 \mathrm{E}$ & $80 \mathrm{E}$ & $70 \mathrm{E}$ & & $\mathrm{E}$ & $S$ & $\mathrm{E} \times \mathrm{S}$ \\
\hline \multicolumn{8}{|l|}{ Daily feed (DM) intake } \\
\hline Concentrate $(\mathrm{g})$ & $315^{\mathrm{c}}$ & $146^{\mathrm{b}}$ & $75^{\mathrm{a}}$ & 3.0 & $* * *$ & NS & NS \\
\hline Wheat straw (g) & 417 & 503 & 477 & 13.4 & NS & $*$ & NS \\
\hline Total $(\mathrm{g})$ & $732^{\mathrm{c}}$ & $648^{\mathrm{b}}$ & $552^{\mathrm{a}}$ & 15.4 & $* *$ & $*$ & NS \\
\hline$\left(\mathrm{g} / \mathrm{kg} \mathrm{W}^{0.75}\right)$ & $56.5^{\mathrm{b}}$ & $53.6^{\mathrm{ab}}$ & $50.4^{\mathrm{a}}$ & 0.81 & $*$ & NS & NS \\
\hline$(\mathrm{g} / \mathrm{kg} \mathrm{LW})$ & 24.1 & 23.4 & 22.7 & 0.32 & NS & NS & NS \\
\hline \multicolumn{8}{|c|}{ Digestibility of nutrients (\%) } \\
\hline $\mathrm{DM}$ & 52.3 & 49.9 & 49.9 & 0.56 & NS & NS & NS \\
\hline $\mathrm{OM}$ & $56.2^{\mathrm{b}}$ & $52.9^{\mathrm{a}}$ & $53.2^{\mathrm{a}}$ & 0.52 & $*$ & NS & NS \\
\hline $\mathrm{CP}$ & $43.46^{\mathrm{b}}$ & $35.4^{\mathrm{a}}$ & $30.4^{\mathrm{a}}$ & 1.21 & $* *$ & NS & NS \\
\hline Ether extract & $66.9^{\mathrm{b}}$ & $44.2^{\mathrm{a}}$ & $51.4^{\mathrm{a}}$ & 1.47 & $* * *$ & $*$ & NS \\
\hline Total carbohydrates & 56.9 & 55.3 & 56.2 & 0.66 & NS & NS & NS \\
\hline $\mathrm{NDF}$ & $46.7^{\mathrm{a}}$ & $50.6^{\mathrm{b}}$ & $52.8^{\mathrm{b}}$ & 0.53 & $* *$ & NS & NS \\
\hline $\mathrm{ADF}$ & $29.1^{\mathrm{a}}$ & $38.6^{\mathrm{b}}$ & $41.9^{\mathrm{b}}$ & 0.84 & $* * *$ & $*$ & $* *$ \\
\hline Hemicellulose & $61.2^{\mathrm{a}}$ & $66.0^{\mathrm{b}}$ & $67.2^{\mathrm{b}}$ & 0.73 & $* *$ & NS & NS \\
\hline \multicolumn{8}{|l|}{ Daily intake of nutrients } \\
\hline $\mathrm{CP}(\mathrm{g})$ & $70.8^{\mathrm{b}}$ & $66.8^{\mathrm{b}}$ & $59.5^{\mathrm{a}}$ & 1.10 & $* *$ & $*$ & NS \\
\hline$\left(\mathrm{g} / \mathrm{kg} \mathrm{W}^{0.75}\right)$ & 5.48 & 5.53 & 5.44 & 0.049 & NS & NS & NS \\
\hline $\mathrm{DCP}(\mathrm{g})$ & $31.1^{\mathrm{c}}$ & $23.8^{\mathrm{b}}$ & $18.3^{\mathrm{a}}$ & 1.02 & $* * *$ & $*$ & NS \\
\hline$\left(\mathrm{g} / \mathrm{kg} \mathrm{W}^{0.75}\right)$ & $2.38^{\mathrm{b}}$ & $1.96^{\mathrm{a}}$ & $1.65^{\mathrm{a}}$ & 0.069 & $* *$ & NS & NS \\
\hline ME (Mcal) & $1.36^{\mathrm{c}}$ & $1.14^{\mathrm{b}}$ & $0.97^{\mathrm{a}}$ & 0.026 & $* * *$ & $* *$ & NS \\
\hline$\left(\mathrm{kcal} / \mathrm{kg} \mathrm{W}^{0.75}\right)$ & $105.5^{\mathrm{b}}$ & $94.0^{\mathrm{a}}$ & $88.9^{\mathrm{a}}$ & 1.40 & $* *$ & NS & NS \\
\hline \multicolumn{8}{|l|}{ Nutrient density } \\
\hline $\mathrm{CP}(\%)$ & $9.82^{\mathrm{a}}$ & $10.33^{\mathrm{ab}}$ & $10.80^{\mathrm{b}}$ & 0.098 & $* *$ & $*$ & NS \\
\hline $\operatorname{DCP}(\%)$ & $4.26^{\mathrm{a}}$ & $3.66^{\mathrm{ab}}$ & $3.27^{\mathrm{b}}$ & 0.132 & $*$ & NS & NS \\
\hline $\mathrm{ME}(\mathrm{Mcal} / \mathrm{kg} \mathrm{DM})$ & 1.88 & 1.75 & 1.77 & 0.020 & NS & NS & NS \\
\hline
\end{tabular}

100E, $80 \mathrm{E}$ and 70E diets were designed to supply 100,80 and $70 \%$, respectively, of energy requirements.

a,b,c Means bearing different superscripts in a row differ significantly.

${ }^{1}$ Significant effect of energy level (E), sex (S) or their interaction $(\mathrm{E} \times \mathrm{S}) . * \mathrm{p}<0.05, * * \mathrm{p}<0.01, * * * \mathrm{p}<0.001$; NS $=\mathrm{Non}-\mathrm{significant}$ 
three diets. The mean intake of $\mathrm{DM}(\mathrm{g} / \mathrm{d})$ through concentrate supplement lowered $(\mathrm{p}<0.01)$ concomitant to reduced dietary energy level. The lambs under $80 \mathrm{E}$ group tended $(\mathrm{p}=0.057)$ to consume more $(+86 \mathrm{~g})$ wheat straw as compared to the control $100 \mathrm{E}$ group, possibly in an attempt to compensate for the reduced availability of energy. The extent of compensatory increase in wheat straw consumption for $70 \mathrm{E}$ lambs $(+60 \mathrm{~g})$ was less than for $80 \mathrm{E}$ lambs. This could be due to a considerably higher proportion of wheat straw $(\sim 79 \%)$ in the $80 \mathrm{E}$ diet, which may relate to the limited physical capacity of the reticulorumen. Furthermore, a very high level of NDF in the $80 \mathrm{E}$ diet might have affected the voluntary intake by eliciting a relatively slow rate of fermentation and increased digesta retention time (Meissner et al., 1991). Consequently, total DMI was lower $(\mathrm{p}<0.01)$ for $80 \mathrm{E}$ and $70 \mathrm{E}$ vs $100 \mathrm{E}$. A significant $(p<0.05)$ effect of sex was apparent in the DM intake, with a greater value for males than for females $(685.5 \pm 31.9$ vs $602.7 \pm 27.5 \mathrm{~g} / \mathrm{d}$ ) mainly due to higher ( $\mathrm{p}<$ $0.05)$ wheat straw consumption. On the contrary, Rodríguez et al. (2008), while studying the effect of varying intake levels in lambs, did not find any effect of sex on feed intake.

The digestibility of DM was not affected by treatment $(p>0.05)$. Digestibilities of OM $(p<0.05), C P(p<0.01)$ and EE $(p<0.001)$ were lower for $80 \mathrm{E}$ and $70 \mathrm{E}$ compared with 100E. Contrary to the present observations, Mahgoub et al. (2000) observed higher DM digestibility in high- than lowenergy diet. The present observations could be explained on the basis of lower intake of concentrates in relation to wheat straw by lambs in the $80 \mathrm{E}$ and $70 \mathrm{E}$ groups, as could be ascertained from the concentrate: roughage ratio of $0.29 \pm$ 0.01 for $80 \mathrm{E}$ and $0.16 \pm 0.01$ for $70 \mathrm{E}$ vis-à-vis $0.79 \pm 0.06$ for $100 \mathrm{E}$ group. Consequently, the apparent positive relationship between dietary energy levels and $\mathrm{OM}$ digestibility could be explained on the basis of a higher microbial fermentation due to increasing levels of concentrate availability. A reduction in the dietary energy level imparted significant $(\mathrm{p}<0.01)$ negative effect on the digestibility of $\mathrm{CP}$ by the lambs of $80 \mathrm{E}$ and $70 \mathrm{E}$ groups. This variation, in spite of the fact that, all the three diets were formulated to be isonitrogenous, was suggestive of the fact that for proper utilization of protein adequacy of dietary energy is of paramount importance.

Total carbohydrate digestibility was not influenced ( $>0.05)$ by treatment, whereas digestibilities of NDF $(p<$ $0.01), \operatorname{ADF}(p<0.001)$ and hemicellulose $(p<0.01)$ were lower for $100 \mathrm{E}$ compared with $80 \mathrm{E}$ and $70 \mathrm{E}$. This variation could be possibly ascribed to the variation in cereal (maize) contents of the concentrate supplements; the high proportion of maize in the concentrate supplement fed to $100 \mathrm{E}$ lambs could possibly have led to a reduction in ruminal $\mathrm{pH}$ attributable to excessive fermentative acid production, consequently depressing cellulolysis and fiber digestion. The potential adverse effect of high starch diets on fiber digestion has also been suggested by Ivey et al. (2000). Intake of CP was lowest $(\mathrm{p}<0.01)$ among treatments for $70 \mathrm{E}$, although when expressed relative to metabolic body size, the values were comparable among treatments. Intake of DCP, however, ranked $(\mathrm{p}<0.001) 100 \mathrm{E}>80 \mathrm{E}>70 \mathrm{E}$, which was attributable to differences in $\mathrm{CP}$ digestibility. Intake of ME in Mcal/d ranked (p<0.01) 100E $>80 \mathrm{E}>70 \mathrm{E}$, although expressed relative to body size ME intake was not different between $80 \mathrm{E}$ and $70 \mathrm{E}$. Significantly $(\mathrm{p}<0.05)$ lower intake of $\mathrm{CP}, \mathrm{DCP}$ and ME by females than male lambs was a reflection of the lower consumption of DM by the females. However, expressed in relation to metabolic body size, the differences between the sexes became nonsignificant.

\section{Nitrogen metabolism}

The data on $\mathrm{N}$ retention of lambs are presented in Table 3. The mean daily $\mathrm{N}$ intake was similar between $100 \mathrm{E}$ and $80 \mathrm{E}$ groups; however it was significantly $(\mathrm{p}<0.01)$ reduced in the low energy $70 \mathrm{E}$ group. There were no treatment differences in faecal and urinary $\mathrm{N}$ excretion. Nevertheless, a closer look into the data is indicative of apparently higher $(\mathrm{p}=0.113)$ urinary $\mathrm{N}$ excretion by lambs under $70 \mathrm{E}$ vs 100E. Consequently, the $\mathrm{N}$ balance $(\mathrm{g} / \mathrm{d})$ showed a gradual reduction $(\mathrm{p}<0.01)$ from 2.57 in $100 \mathrm{E}$ to 1.38 in $80 \mathrm{E}$ and -0.17 in $70 \mathrm{E}$ lambs. Similar to the present findings, Chandramoni et al. (1999) and Giraldez et al. (1999) have also observed lower nitrogen retention upon feeding of low energy diets. Although the diets in the present experiment were made isonitrogenous, the lower $\mathrm{N}$ retention by $80 \mathrm{E}$ and $70 \mathrm{E}$ lambs was indicative of inefficient utilization of nitrogen due to unavailability of adequate energy. Moreover, as the deficit was more intense in the case of $70 \mathrm{E}$, consequently it led to a net loss of nitrogen. This variation in nitrogen metabolism could be better explained by the observations that because of normal rumen metabolism, it is difficult to alter energy intake without affecting the amount of microbial protein synthesized in the rumen and, consequently, the total protein supply to the animal (Schroeder and Titgemeyer, 2008). Upon considering the nitrogen retention as a percentage of either intake or absorbed nitrogen, the persistence of the same trend was a reflection of the fact that energy deficit significantly affected the nitrogen utilization both at the rumen as well as at cellular level. There are reports in sheep that hypocaloric diets adequate in proteins did not interfere with the nitrogen balance (Hovell et al., 1983; Ørskov et al., 1983) because of the mobilization of endogenous energy (presumably body fat) to meet the energy needs of protein anabolism (Chowdhury, 1990). However in the present study, with the animals in the active growth phase, not much depot fat could be expected. 
Table 3. Nitrogen balance and live weight change in lambs fed varied levels of dietary energy

\begin{tabular}{|c|c|c|c|c|c|c|c|}
\hline \multirow{2}{*}{ Parameter } & \multicolumn{3}{|c|}{ Dietary groups } & \multirow{2}{*}{ SEM } & \multicolumn{3}{|c|}{ Significance $^{1}$} \\
\hline & $100 \mathrm{E}$ & $80 \mathrm{E}$ & $70 \mathrm{E}$ & & $\mathrm{E}$ & $\mathrm{S}$ & $\mathrm{E} \times \mathrm{S}$ \\
\hline \multicolumn{8}{|l|}{ Nitrogen balance } \\
\hline Intake (g/ d) & $11.3^{\mathrm{b}}$ & $10.7^{\mathrm{b}}$ & $9.5^{\mathrm{a}}$ & 0.18 & $* *$ & $*$ & NS \\
\hline \multicolumn{8}{|l|}{ Excretion } \\
\hline Faecal (g/d) & 6.40 & 6.87 & 6.59 & 0.115 & NS & NS & NS \\
\hline Urinary (g/d) & 2.36 & 2.43 & 3.10 & 0.150 & NS & NS & NS \\
\hline \multicolumn{8}{|l|}{ Retention } \\
\hline $\mathrm{g} / \mathrm{d}$ & $2.57^{\mathrm{c}}$ & $1.38^{\mathrm{b}}$ & $-0.17^{\mathrm{a}}$ & 0.199 & $* * *$ & NS & NS \\
\hline As \% intake $\mathrm{N}$ & $22.4^{\mathrm{c}}$ & $12.5^{\mathrm{b}}$ & $-2.02^{\mathrm{a}}$ & 0.02 & $* * *$ & NS & NS \\
\hline As \% absorbed $\mathrm{N}$ & $51.4^{\mathrm{b}}$ & $33.5^{\mathrm{b}}$ & $-9.1^{\mathrm{a}}$ & 0.05 & $* *$ & NS & NS \\
\hline \multicolumn{8}{|l|}{ Live weight change } \\
\hline Initial $(\mathrm{kg})$ & 26.57 & 26.66 & 26.65 & 3.108 & NS & $* *$ & NS \\
\hline Final $(\mathrm{kg})$ & $35.03^{\mathrm{c}}$ & $29.10^{\mathrm{b}}$ & $23.65^{\mathrm{a}}$ & 3.036 & $* * *$ & $* *$ & $*$ \\
\hline Net change (kg) & $8.46^{\mathrm{c}}$ & $2.44^{\mathrm{b}}$ & $-3.00^{\mathrm{a}}$ & 1.017 & $* * *$ & NS & $* *$ \\
\hline Average daily gain (g) & $47.01^{\mathrm{c}}$ & $13.54^{\mathrm{b}}$ & $-16.67^{\mathrm{a}}$ & 31.518 & $* * *$ & NS & $* *$ \\
\hline
\end{tabular}

100E, 80E and 70E diets were designed to supply 100, 80 and $70 \%$, respectively, of energy requirements.

a,b,c Means bearing different superscripts in a row differ significantly.

${ }^{1}$ Significant effect of energy level (E), sex (S) or their interaction $(\mathrm{E} \times \mathrm{S}) . * \mathrm{p}<0.05, * * \mathrm{p}<0.01, * * * \mathrm{p}<0.001, \mathrm{NS}=\mathrm{Non}-\mathrm{significant}$.

\section{Live weight changes and growth performance}

The data on growth performance is presented in Table 3, and fortnightly pattern of live weight (LW) changes are depicted in Figure 1. Initial weights, although similar among the three groups, were more $(\mathrm{p}<0.01)$ for males than females. The final $\mathrm{LW}$, net gain as well as the average daily gain (ADG) at the end of 180 days exhibited significant $(\mathrm{p}<0.001)$ interaction between treatment and gender. But for all the interaction in LW changes, the variation between genders was due to varying magnitudes (not gain for one and loss for another). Accordingly, the data are interpreted with attention to main effects rather than interactions. Further, the lambs on diet 70E exhibited a negative ADG which differed significantly $(p<0.001)$ from both $100 \mathrm{E}$ and $80 \mathrm{E}$. It has been suggested that increasing level of feeding to increase energy supply could be associated not only with greater energy supply, but also with a greater total protein supply and an increase in the ratio of metabolizable protein: energy; thus, it is almost impossible to discern if the animals were increasing growth in response to additional supply of energy or protein (Schroeder and Titgemeyer, 2008). To counter this expected confusion, all the groups were fed at a uniform level of $25 \mathrm{~g} / \mathrm{kg} \mathrm{LW}$. However, in spite of this, the resultant ratio between DCP:ME showed a decline with reducing levels of dietary energy, the values being $0.227,0.209$ and 0.185 for $100 \mathrm{E}, 80 \mathrm{E}$ and $70 \mathrm{E}$ groups, respectively. This variation, in turn, had significant impact on the protein utilization (Table 3), and consequently growth performance of the lambs.

A significant $(p<0.01)$ interaction between energy levels and sex was apparent in the ADG by lambs. Accordingly, ADG for females $(35.56 \pm 2.08 \mathrm{~g})$ was lower than males

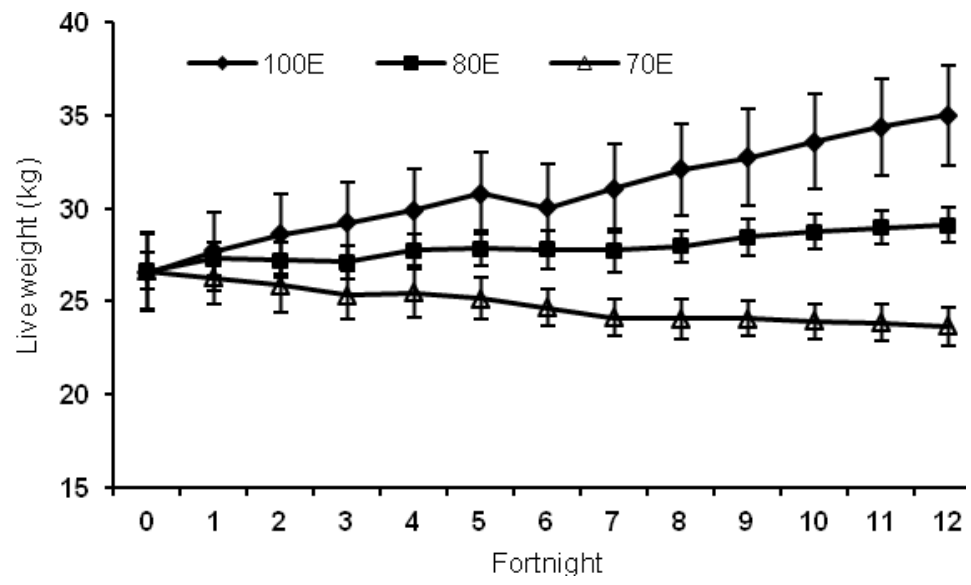

Figure 1. Live weight changes of lambs fed 100 (100E), 80 (80E) and 70 (70E) percent of energy requirements. Values are expressed as mean \pm SE. 
Table 4. Clinical chemistry of experimental lambs fed varied levels of dietary energy

\begin{tabular}{|c|c|c|c|c|c|}
\hline \multirow{2}{*}{ Parameter } & \multicolumn{3}{|c|}{ Dietary groups } & \multirow{2}{*}{ SEM } & \multirow{2}{*}{ Significance } \\
\hline & $100 \mathrm{E}$ & $80 \mathrm{E}$ & $70 \mathrm{E}$ & & \\
\hline Hemoglobin (g/dl) & $9.37^{\mathrm{b}}$ & $7.82^{\mathrm{a}}$ & $7.51^{\mathrm{a}}$ & 0.18 & $* * *$ \\
\hline Haematocrit (\%) & $27.66^{\mathrm{b}}$ & $23.31^{\mathrm{a}}$ & $22.78^{\mathrm{a}}$ & 0.52 & $* * *$ \\
\hline Glucose (mg/dl) & $51.87^{\mathrm{b}}$ & $48.78^{\mathrm{a}}$ & $47.51^{\mathrm{a}}$ & 0.94 & $*$ \\
\hline Total protein $(\mathrm{g} / \mathrm{dl})$ & $5.89^{\mathrm{b}}$ & $5.78^{\mathrm{b}}$ & $5.41^{\mathrm{a}}$ & 0.06 & $*$ \\
\hline Albumin (g/dl) & 3.36 & 3.31 & 3.22 & 0.06 & NS \\
\hline Globulin (g/dl) & 2.43 & 2.47 & 2.21 & 0.08 & NS \\
\hline AG ratio & 1.46 & 1.37 & 1.39 & 0.07 & NS \\
\hline Urea (mg/dl) & $22.84^{\mathrm{c}}$ & $27.03^{\mathrm{b}}$ & $31.00^{\mathrm{a}}$ & 0.62 & $* * *$ \\
\hline Cortisol (ng/ml) & $13.66^{\mathrm{b}}$ & $8.41^{\mathrm{a}}$ & $7.48^{\mathrm{a}}$ & 0.67 & $* * *$ \\
\hline $\operatorname{TLC}\left(\times 10^{3} / \mathrm{mm}^{3}\right)$ & $10.43^{\mathrm{c}}$ & $8.53^{\mathrm{b}}$ & $7.80^{\mathrm{a}}$ & 0.28 & $* * *$ \\
\hline \multicolumn{6}{|c|}{ Differential leukocyte count (\%) } \\
\hline Lymphocyte & $56.44^{\mathrm{b}}$ & $55.00^{\mathrm{b}}$ & $52.25^{\mathrm{a}}$ & 0.95 & $* *$ \\
\hline Monocyte & $2.69^{\mathrm{c}}$ & $1.50^{\mathrm{a}}$ & $2.03^{\mathrm{b}}$ & 0.25 & $* * *$ \\
\hline Neutrophil & $37.53^{\mathrm{a}}$ & $41.31^{\mathrm{b}}$ & $42.56^{\mathrm{b}}$ & 1.12 & $* * *$ \\
\hline Basophil & 0.19 & 0.13 & 0.09 & 0.04 & NS \\
\hline Eosinophil & $2.88^{\mathrm{b}}$ & $2.06^{\mathrm{a}}$ & $3.06^{\mathrm{b}}$ & 0.30 & $* *$ \\
\hline $\mathrm{N}:$ L ratio & $0.66^{\mathrm{a}}$ & $0.75^{\mathrm{b}}$ & $0.81^{\mathrm{c}}$ & 0.06 & $* *$ \\
\hline
\end{tabular}

$100 \mathrm{E}, 80 \mathrm{E}$ and $70 \mathrm{E}$ diets were designed to supply 100,80 and $70 \%$, respectively, of energy requirements.

${ }_{a, b, c}$ Means bearing different superscripts in a row differ significantly. $* \mathrm{p}<0.05, * * \mathrm{p}<0.01, * * * \mathrm{p}<0.001$.

$\mathrm{TLC}=$ Total leukocyte count; N:L ratio = neutrophil: lymphocyte ratio.

$(58.47 \pm 4.24 \mathrm{~g})$ on $100 \mathrm{E}$ diet while both males $(12.08 \pm 2.91$ $\mathrm{g})$ and females $(14.58 \pm 2.34 \mathrm{~g})$ attained similar ADG when fed on $80 \mathrm{E}$ diet. In contrast, although both the sexes had negative ADG, females $(-3.89 \pm 3.71 \mathrm{~g})$ typically showed higher values than their male $(-29.44 \pm 13.95 \mathrm{~g})$ counterparts when fed on 70E diet. The percent decrease in ADG while reducing the energy level from $100 \mathrm{E}$ through $80 \mathrm{E}$ (79\% in males vs $59 \%$ in females) to $70 \mathrm{E}$ ( $150 \%$ in males vs $111 \%$ in females) was lesser in female than male lambs. This, when considered in conjunction with the similar per unit $\left(\mathrm{kg} \mathrm{W}^{0.75}\right.$ ) intake of CP, DCP and ME by both the sexes (see data in Table 2), clearly indicates that males are more susceptible to energy restrictions in terms of growth than females, and this may be related to their higher requirements for energy. It was due to this confounding effect of dietary energy level with gender that no effect of sex was evident $(p>0.05)$ on the growth of lambs, in contrast to such reports by various workers (Santra and Karim, 1999; Rodríguez et al., 2008). The present findings of better growth upon high energy diets are similar to observations in sheep by Mahgoub et al. (2000). Boulanouar et al. (1995) have also observed reduced LW gain in ewe lambs given energy and/or protein restricted diets than control. Jordanovski (1993), however, observed no influence of dietary energy level on the LW gain of early weaned lambs, when fed on isonitrogenous basis.

\section{Clinical chemistry}

The observations on the clinical chemistry of the lambs are presented in Table 4. The hemoglobin concentration reduced significantly $(\mathrm{p}<0.001)$ in $80 \mathrm{E}$ and $70 \mathrm{E}$ group of lambs in comparison to $100 \mathrm{E}$. The haematocrit values also followed a similar trend. The lower $\mathrm{Hb}$ and haematocrit in the energy-deficient groups are a reflection of reduced dietary protein availability as could be ascertained from the reduced nitrogen utilization by these groups (Table 3). Likewise, Farrell et al. (1972) and Oetzel et al. (1988) have also observed lowered $\mathrm{Hb}$ and haematocrit in sheep upon feed restriction meant for reducing dietary availability of protein. It has been suggested that a severe protein deficiency interferes with $\mathrm{Hb}$ production (Whitehair, 1958).

Serum glucose level was significantly $(\mathrm{p}<0.05)$ lower in both the energy-deficient groups in comparison to 100E. The higher level of protein intake in energy restricted condition causes an increase in energy deficiency (Yurtman et al., 2002), which may eventually result in reduced serum glucose with concomitant increase in serum urea (Hibbitt, 1988). In the present study also, serum levels of urea were increased $(p<0.001)$ in both the energy-deficient groups. Earlier studies by Schrick et al. (1990) are also indicative of higher urea levels due to dietary energy restrictions. It could have resulted from a higher rate of amino acid catabolism to compensate for the deficiency of energy (glucose) or an imbalance of amino acids reaching the small intestine, as has been suggested by Abdelgadir et al. (1996). Blood urea nitrogen has been suggested as a useful indicator for nitrogen (protein) utilization in ruminants (Kohn et al., 2005). 
The serum total protein was found to be significantly $(\mathrm{p}<0.05)$ low in $70 \mathrm{E}$ lambs as compared to $100 \mathrm{E}$ or $80 \mathrm{E}$, while no variation was observed in the serum concentrations of albumin and globulin. Dietary protein deprivation has been reported to induce lower levels of serum total protein (Sahoo et al., 2009), which, as a matter of fact, is the situation in the present study as well. Contrary to the present observations, Ivey et al. (2000) observed no effects of dietary energy variations in serum total proteins.

The TLC values exhibited a consistent declining trend $(\mathrm{p}<0.01)$ as the energy availability reduced from 100 to 70 percent. This could be attributed to a possible reduction in synthesis of leukocytes because of lower availability of both energy and protein. Moreover, it could also be correlated to the reported atrophy of thymus due to malnutrition (Fiske and Adams, 1985). The perusal of the DLC data (Table 4) revealed that the concentrations of all the cell types, with the exception of basophills, were significantly influenced by dietary energy availability. The neutrophil concentration showed an increase $(\mathrm{p}<0.01)$ in the energy-starved $80 \mathrm{E}$ and $70 \mathrm{E}$ groups (41.31 and $42.56 \%$ ) as compared to the control $100 \mathrm{E}(37.53 \%)$. Contrary to the above, lymphocyte ratio was significantly $(\mathrm{p}<0.05)$ lower in $70 \mathrm{E}(52.25 \%)$ as compared to $80 \mathrm{E}(55.0 \%)$ or $100 \mathrm{E}$ $(56.44 \%)$. The latter could have been due restricted lymphocyte proliferation because of reduced nutrient availability as suggested by Fisk and Adams (1985). Leukocytes subpopulation are known to vary because of several factors viz. age, sex, diet and environment etc.

The mean serum level of cortisol varied significantly ( $<<0.001)$ among the groups; showing a definite reduction consequent to reduced availability of dietary energy. The values obtained in the present study ( 7 to $14 \mathrm{ng} / \mathrm{ml}$ ) falls within the reported plasma cortisol ranges for sheep (Fell et al., 1985; Ekpe and Christopherson, 2000; Kiyma et al., 2004). Similar to our findings, Sticker et al. (1995) also observed a significantly reduced plasma cortisol concentration in mares fed diet restricted to 50 per cent of the ME requirements. Wynn et al. (1988), on the other hand, observed no changes in plasma cortisol in relation to nutrition when sheep were fed at two levels (5.2 or 9.7 $\mathrm{MJ} / \mathrm{d}$ ) of energy. Likewise, Adam et al. (1997) also observed no effect of supplying 0.5 or 1.5 times of maintenance energy requirements on plasma cortisol levels of weathers. There are a number of studies which observed no effects of dietary fasting or variable dietary energy or malnutrition on serum cortisol and calves (Griebel et al., 1987; Ofay and Rosenguist, 1988), cows (Schrick et al., 1990), or ewes (Kiyma et al., 2004). Contrary to these findings, feed restriction of Suffolk-cross lambs is reported to have significantly increased the plasma cortisol compared to those fed ad libitum (Ekpe and Christopherson, 2000). Because of the metabolic role of cortisol in increasing gluconeogenesis, lipolysis, and protein catabolism, it would appear that nutrient restriction should increase circulating cortisol concentrations and facilitate nutrient mobilization. However, the lack of such an effect in the present situation could possibly be attributed to long duration of the dietary restrictions employed in this study. In fact, Sticker et al. (1995) have concluded that a gradual reduction in average cortisol concentrations in mares fed low energy diet and attributed the same to prolonged nutrient restriction.

\section{Immune response}

Several immune parameters have been proposed as markers of chronic stressful situations in farm animals including antibody production, an increase in the ratio between neutrophils and lymphocytes (N/L ratio) and functional activity of peripheral blood mononuclear cells (Trevisi and Bertoni, 2009). The N/L ratio in the present study showed progressively higher values $(\mathrm{p}<0.01)$ with decreased dietary energy levels (Table 4), which is indicative of stress. A higher $\mathrm{N} / \mathrm{L}$ ratio may also indicate a health challenge to the animal, reflecting a weakened immune system and often, consequently, an animal in poor health (Hyun et al., 2005). Consequently, the observed higher N/L ratio in both the low energy groups is possibly indicative of a weakening of the immune system of the lambs.

\section{Antibody response}

Results on humoral immune response, assessed by monitoring the serum antibody against heat killed $B$. abortus S19 soluble antigen, are presented in Figure 2. The pre-inoculation screening of the lambs for Brucella infection through RBPT revealed absence of antibody, implying that the herd was free from prior infection or sensitization. The antibody level (expressed as $\mathrm{A}_{492}$ ) was significantly $(\mathrm{p}<0.05)$ reduced in both the energy deprived groups $80 \mathrm{E}$ and $70 \mathrm{E}$ at $7 \mathrm{~d}$ post-inoculation as compared to $100 \mathrm{E}$ group, indicative of reduced initial antibody production. However, at subsequent periods, the antibody level did not differ among the three groups reflecting of identical humoral immune response. The present observation of lower antibody response on $\mathrm{d} 7$ followed by a subsequent identical response apparently corroborates the findings of Gropp and Birzer (1989) which reported that severe protein energy malnutrition causes immunosuppression by delaying humoral antibody reaction, among other factors. Overall, however, the dietary alterations in terms of energy apparently induced no perceptible negative effects on the humoral immunity of the lambs. The present observations are in agreement with the reports of Olson and Bull (1986) who observed no major or sustained differences in the humoral response of beef cows 


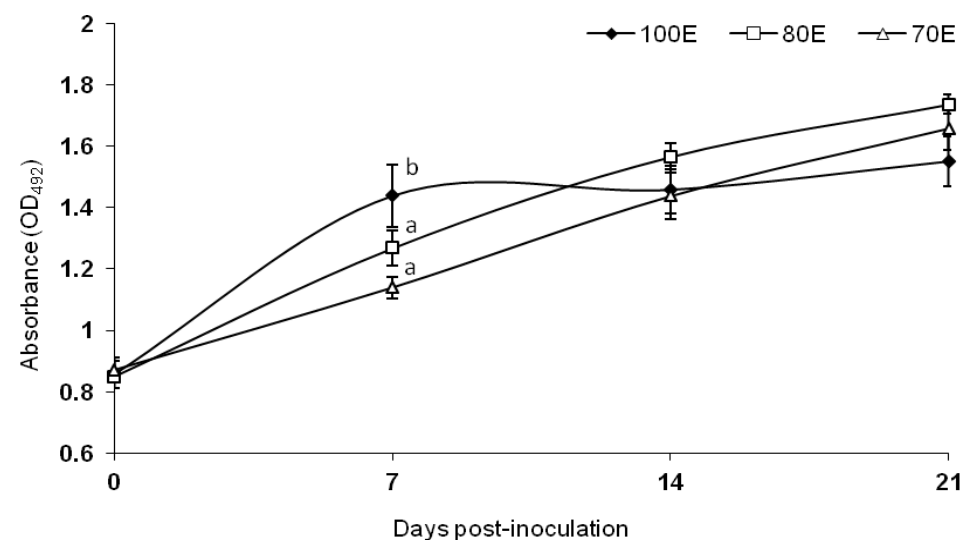

Figure 2. Antibody titre against Brucella abortus S19 antigen by lambs fed 100 (100E), 80 (80E) and 70 (70E) percent of energy requirements. Values are expressed as mean \pm SE; superscripts $\left({ }^{a, b}\right)$ indicate significant $(\mathrm{p}<0.05)$ differences between the groups.

due to energy and/or protein restriction, in spite of differences in antibody titers to tetanus toxoid or chicken RBC. Similar to the present observations, Fiske and Adams (1985) have reported no difference in antibody response to B. abortus S19 antigen in groups of steers fed on low, normal or high plane of nutrition. On the other hand, they have observed reduced antibody response to chicken RBC accompanying thymus atrophy in the underfed steers in the same study. Jacobi et al. (1997) in a study exploring the correlation between somatic cell counts of milk with feed imbalances suggested that protein synthesis affected by energy deficiency reduces humoral immunity. In the present study also a state of protein deficiency was observed in $70 \mathrm{E}$ group of lambs fed 70 per cent of $80 \mathrm{E}$ requirements, as could be ascertained form the nitrogen metabolism data (Table 3); however, no adverse effect of this secondary protein deficiency was apparent on the humoral immunity of the lambs, other than a delayed response.

\section{Delayed-type hypersensitivity response}

The results of the DTH response are presented graphically in Figure 3. Animals under all the three dietary groups exhibited an increase in indurations of skin following the intra-dermal injection of PHA-P. However, averaged across the post-inoculation measurements, the mean skin thickness exhibited significantly $(p<0.01)$ lower values in animals under both the energy-restricted groups ( $3.48 \pm 0.14$ and $3.37 \pm 0.13$ vs $3.89 \pm 0.18 \mathrm{~mm})$, indicative of significantly reduced CMI response. Reduced skin thickness following sensitization with PHA-P upon protein restriction was also recorded in sheep by Sahoo et al. (2009). Feed restriction of ewes has been reported to reduce the response to delayed hypersensitivity tests (Oetzel et al., 1988). Latshaw (1991) has suggested that cellular integrity is very important for receiving and responding to messages needed to coordinate an immune response. The affection of cellular integrity because of oxidative stress, therefore, may eventually lead to a reduced immune response. In the present study, a significant $(\mathrm{p}<0.05)$ increase in lipid peroxidation was observed in the energy-restricted groups (Singh et al., 2011), which happens to be a good indicator of oxidative damage of cell membrane. Hence, this could also explain, at least in part, the reduced CMI response due to energy restriction. Further, accumulating levels of DNA

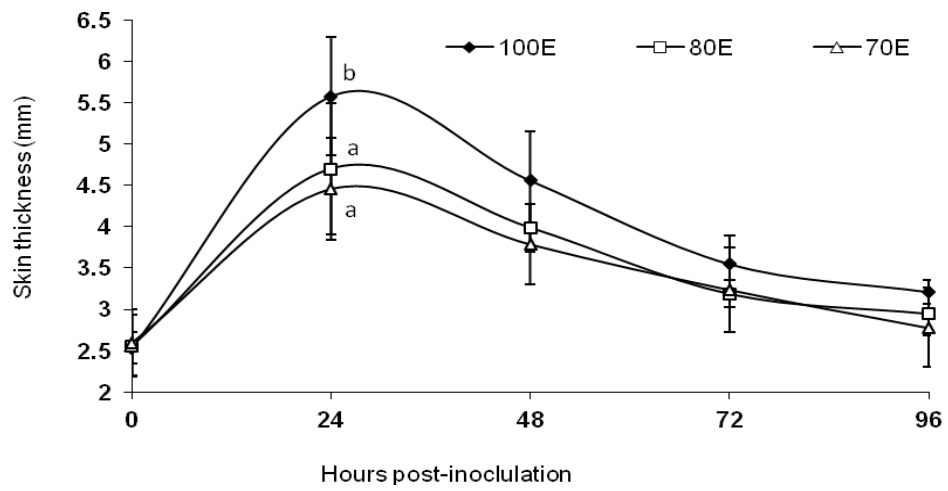

Figure 3. DTH response of lambs fed $100(100 \mathrm{E}), 80(80 \mathrm{E})$ and $70(70 \mathrm{E})$ percent of energy requirements. Values are expressed as mean \pm SE; superscripts $(a, b)$ indicate significant $(p=0.066)$ differences between the groups. 
damage, induced by oxidative damage, may also cause reduced cellular function that potentially leads to suboptimal immune response (Barnett and Barnett, 1998). Fiske and Adams (1985) observed non-significant differences in the lymphocyte blastogenic responses of steers fed hypo- and hyper-alimented diets to concanavalinA and pokeweed. However, Woodward et al. (1980) have suggested from a study involving bovines that nutritional factors (deficiencies) influence the mitogenic responses to $\mathrm{T}$ lymphocytes, which corroborates the present finding.

\section{Nitric oxide production}

The mean values for nitrite, as an indicator of NO production by lymphocytes, are presented in Figure 4. Dietary energy variations employed in the present study imparted significant influence on the nitrite production, both basal as well as upon lipopolysaccharide (LPS) stimulation; the basal nitrite production $(\mu \mathrm{M})$ reduced significantly $(\mathrm{p}<0.01)$ in the energy restricted $80 \mathrm{E}(3.65 \pm$ $0.19)$ and $70 \mathrm{E}(3.78 \pm 0.14)$ groups compared to the control group $(5.17 \pm 0.27)$. The corresponding values following LPS stimulation $(4.29 \pm 0.64$ and $4.33 \pm 0.24$ vs $6.84 \pm 0.89$ $\mu \mathrm{M})$ also followed the similar trends. These results indicate that dietary energy restriction reduced both the constitutive and inducible production of NO by lymphocytes. The PBMC, incubated with different mitogens to induce nonspecific multiplication on lymphocyte, have shown a consistent depression of mitogenesis under chronic stressful situations in ruminants (Trevisi and Bertoni, 2009). The present observations are in confirmation of the reported positive relationship between energy balance of periparturient cows with lymphocyte response to mitogens like PHA, Con A and poke weed (Ropstad et al., 1989). It is now recognized that NO produced by many cell types plays a vital role in host defense and immunity, including the modulation of inflammatory responses (Christopherson and Bredt, 1997). It has been suggested by Clancy et al. (1998) that the finding of increased NO production is viewed as a reflection of an immune-activated state in which inflammatory cytokines and other mediators have upregulated inducible NO production. With nitrite production been recognized as a measure of CMI response in several species (Roach et al., 1995; Zhao et al., 1997), the present findings of significantly lower in vitro production of nitrite by lymphocytes of lambs upon energy deprived diets appears to be further confirmation of the lower CMI response observed in the said groups as assessed through DTH response to PHA-P.

Traditionally, immune functions have been regarded as part of maintenance (Houdijk et al., 2001). However, there is an increasing body of evidence that at least some aspects of immunity are sensitive to changes in nutrient supply (Coop and Kyriazakis, 1999; Galyean et al., 1999), because of increased nutritional costs associated with the development of an effective immune response (Lochmiller and Deerenberg, 2000). However, if nutrient availability is scarce, it requires a trade-off between mounting an immune response and other body functions like growth and reproduction (Doeschl-Wilson et al., 2009). As immunological functions are prioritized over productive function (Coop and Kyriazakis, 1999), it is expected that a growing animal would try to maintain its immune function at the cost of growth; and the observation of low/negative growth exhibited by $80 \mathrm{E}$ and $70 \mathrm{E}$ lambs in the present study gives credence to the above theory. There is ample research available studying the nutrient partitioning between immune function and reproduction, which have ranked reproduction ahead of immune function. Similarly, studies in dairy cows have indicated that the metabolic

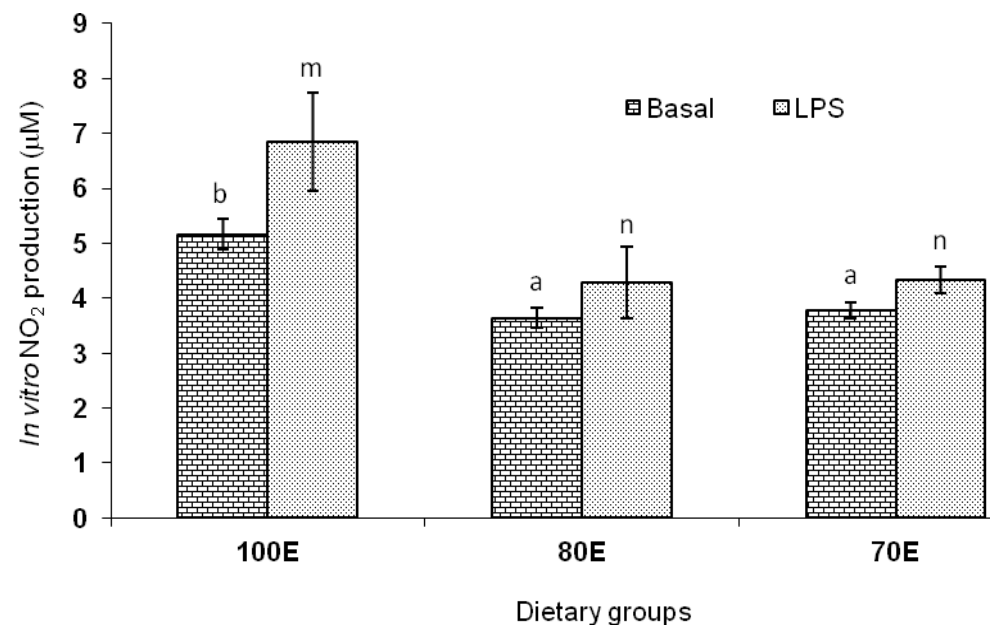

Figure 4. In vitro nitrite production by peripheral lymphocytes of lambs fed 100 (100E), 80 (80E) and 70 (70E) percent of energy requirements. Values are expressed as mean $\pm \mathrm{SE}$; superscripts indicate significant differences between the groups $\left({ }^{\mathrm{a}, \mathrm{b}} \mathrm{p}<0.001 ;{ }^{\mathrm{m}, \mathrm{n}}\right.$ $\mathrm{p}<0.01)$. 
components of negative energy balance were associated with a deficiency in the functions of the immune system in vitro (Suriyasathaporn et al., 1999; Lacetera et al., 2002; Scalia et al., 2006). It has been suggested that dairy cows with negative energy balance are predisposed to liver damage and increased peripheral insulin resistance, both of which can have a negative impact on the immune system (Wathes et al., 2009). However, specific studies targeting prioritization of functions between growth and immunity including elucidation of the underlying homeorrhectic mechanisms involved are scarce. In the absence of such information, it would be reasonable to hypothesize that a growing animal prioritizes immune function ahead of growth, and this could be the reason behind the almost similar level of humoral immune response recorded in the present study. However, the compromise in CMI response recorded could be attributed to apparent long duration of nutrient deprivation (180 d).

\section{CONCLUSION}

The most obvious constraint of experimental approaches based on dietary manipulation is the impossibility of altering the energy supply of the animals without affecting the amount of microbial protein synthesized in the rumen (Schroeder and Titgemeyer, 2008). In the present experiment also, the same constraint was evident, which possibly confounded the effects of dietary energy on the parameters assessed. Nonetheless, considering the obligatory interrelationship between dietary energy and protein in ruminants, and based on the overall results, it could be concluded that reduced levels of dietary energy impacted significantly the protein metabolism even though the diets provided adequate protein. Consequently, lambs on energy deficient diets exhibited reduced nutrient utilization, lowered growth and compromised cell-mediated immunity accompanying a delayed onset of the humoral response. Further, the study highlights the prioritization of immune function over growth in growing lambs reared in a normal non-infectious set up.

\section{ACKNOWLEDGEMENTS}

The authors are thankful to the Director, Indian Veterinary Research Institute, for providing the necessary facilities to carry out the study. The first author thankfully acknowledges the financial assistance in the form of Junior Research Fellowship provided to him by the Deemed University, Indian Veterinary Research Institute, Izatnagar, India.

\section{REFERENCES}

Abdelgadir, I. E. O., J. L. Morrill, and J. J. Higgins. 1996. Effect of roasted soybeans and corn on performance and ruminal and blood metabolites of dairy calves. J. Dairy Sci. 79:465-474.

Adam, C. L., P. A. Findlay, C. E. Kyle, P. Young, and J. G. Mercer. 1997. Effect of chronic food restriction on pulsatile leutinizing hormone secretion and hypothalamic neuropeptide $\mathrm{Y}$ gene expression in castrate male sheep. J. Endocrinol. 152:329-337.

Alton, G. G., L. M. Jones, and D. E. Pietz. 1975. Laboratory Techniques in Brucellosis, 2nd edn. WHO Monograph Series 55, World Health Organization, Geneva.

AOAC. 1995. Official methods of analysis. 16th edn. Association of Official Analytical Chemists, Arlington, Virginia. pp. 4.14.17 .

Atti, N., and F. Bocquier. 1999. Adaptive capacity of Barbary ewes to underfeeding and re-feeding periods: effects on adipose tissues. Annales de Zootechnie 48:189-198.

Barnett, Y. A., and C. R. Barnett. 1998. DNA damage and mutation: contributors to the age related alteration in $\mathrm{T}$ cell mediated immune responses. Mech. Ageing Dev. 102:165-175.

Ben Salem, H., and T. Smith. 2008. Feeding strategies to increase small ruminant production in dry environments. Small Rumin. Res. 77:174-194.

Boulanouar, B., M. Ahmed, T. Klopfenstein, D. Brink, and J. Kinder. 1995. Dietary protein or energy restriction influences age and weight at puberty in ewe lambs. Anim. Reprod. Sci. 40:229-238.

Boyum, A. 1968. Separation of leucocytes from blood and bone marrow. Scand. J. Clin. Lab. Invest. 21(Suppl. 97):31-89.

Chandramoni, S. B. Jadhao, C. M. Tiwari, and M. Y. Khan. 1999. Carbon and nitrogen balance studies in Muzaffarnagari sheep fed diets varying in roughage and concentrate ratio. Small Rumin. Res. 31:221-227.

Chowdhury, S. A., E. R. Ørskov, and N. A. MacLeod. 1990. Protein utilization during energy under nutrition in steers. Proc. Nutr. Soc. 49:208A.

Christopherson, K. S., and D. S. Bredt. 1997. Perspective series: nitric oxide and nitric oxide synthases. Nitric oxide in excitable tissues: physiologic roles and disease. J. Clin. Invest. 100:2424-2429.

Clancy, R. M., A. R. Amin, and S. B. Abramson. 1998. The role of nitric oxide in inflammation and immunity. Arthritis Rheum. 41:1141-1151.

Coop, R. L., and I. Kyriazakis. 1999. Nutrition-parasite interaction. Vet. Parasitol. 84:187-204.

Devendra, C., and C. C. Sevilla. 2002. Availability and use of feed resources in crop-animal systems in Asia. Agric. Syst. 71:5973.

Doeschl-Wilson, A. B., W. Brindle, G. Emmans, and I. Kyriazakis. 2009. Unravelling the relationship between animal growth and immune response during micro-parasitic infections. PLoS ONE 4, e7508. doi:10.1371/journal.pone.0007508.

Doreau, M., B. Michalet-Doreau, P. Grimaud, N. Atti, and P. Nozière. 2003. Consequences of underfeeding on digestion and absorption in sheep. Small Rumin. Res. 49:289-301.

Ekpe, E. D., and R. J. Christopherson. 2000. Metabolic and endocrine responses to cold and feed restriction in ruminants. Can. J. Anim. Sci. 80:87-95.

Farrell, D. J., R. A. Leng, and J. L. Corbett. 1972. Undernutrition in grazing sheep. 1. Changes in the composition of the body, blood and rumen contents. Aust. J. Agric. Res. 23:483-497. 
Fell, L. R., D. A. Shutt, and J. Bentley. 1985. Development of a salivary cortisol method for detecting changes in plasma "free" cortisol arising from acute stress in sheep. Aust. Vet. J. 62:403406.

Fiske, R. A., and L. G. Adams. 1985. Immune responsiveness and lymphoreticular morphology in cattle fed hypo and hyper alimentative diets. Vet. Immunol. Immunopathol. 8:225-244.

Gaal, T., M. Mezes, O. Miskucza, and P. Ribiczey-Szabo. 1993. Effect of fasting on blood lipid peroxidation parameters of sheep. Res. Vet. Sci. 55:104-107.

Galyean, M. L., L. J. Perino, and G. C. Duff. 1999. Interaction of cattle heath/immunity and nutrition. J. Anim. Sci. 77:11201134.

Giraldez, F. J., P. Frutos, P. Lavin, and A. R. Mantecon. 1999. Body composition changes and energy retention in milk-fed lambs undergoing energy restriction. Small Rumin. Res. 31:127-133.

Green, L. C., D. A. Wagner, J. Glogowski, P. L. Skipper, J. S. Wishnok, and S. R. Tanenbaum. 1982. Analysis of nitrate, nitrite and $[15 \mathrm{~N}]$ nitrate in biological fluids. Anal. Biochem. 126:131-138.

Griebel, P. J., M. Schoondeswoerd, and L. A. Babink. 1987. Ontogeny of the immune response: effect of protein energy malnutrition in neonatal calves. Can. J. Vet. Res. 51:428-435.

Gropp, J., and D. Birzer. 1989. Nutritionally not microbially induced immunosuppression. Ubersich. Tierernahr. 17:85-97.

Hibbitt, K. G. 1988. Effect of protein on the health of dairy cows. In: Recent Developments in Ruminant Nutrition, Vol. 2 (Ed. W. Haresign and D. J. A. Cole) Butterworths, London, UK. pp. 184-186.

Houdijk, J. G. M., N. S. Jessop, and I. Kyriazakis. 2001. Nutrient partitioning between reproductive and immune functions in animals. Proc. Nutr. Soc. 60:515-525.

Hovell, F. D. DeB, E. R. Ørskov, N. A. MacLeod, and I. McDonald. 1983. The effect of change in amount of energy infused as volatile fatty acids on the nitrogen retention and creatinine excretion of lambs absolutely nourished by intragastric infusion. Br. J. Nutr. 50:331-343.

Hyun, Y., M. Ellis, S. E. Curtis, and R. W. Johnson. 2005. Environmental temperature, space allowance, and regrouping: Additive effects of multiple concurrent stressors in growing pigs. J. Swine Health Prod. 13:131-138.

Ivey, D. S., F. N. Owens, T. Sahlu, T. H. Teh, L. J. Dawson, G. A. Campbell, and A. L. Goetsch. 2000. Influences of the number of foetuses and lambs of $\mathrm{CP}$ and ME in gestation and lactation supplements on performance of Spanish does and kids during suckling and post-weaning. Small Rumin. Res. 35:123-132.

Jacobi, U., E. Kirst, and K. Krenkel. 1997. Correlations between somatic cell counts of milk and the feeding regime for lactating cattle. DMZ Lebensmittelindustrie und Milchwirtschaft 118:1077-1084.

Jain, M. C. 1986. Schalm's Veterinary Haematology. $4^{\text {th }}$ edn. Lea and Febiger, Philadelphia.

Jordanovski, N. 1993. Effect of dietary energy level on growth performance of early weaned lambs fattened to 84 days old. Krmiva 35:173-178.

Kearl, L. C. 1982. Nutrient requirements of ruminants in developing countries. International Feedstuff Institute, Utah
Agricultural Experiment Station. Utah State University, Logon, Utah, USA.

Kiyma, Z., B. M. Alexander, E. A. Van Kirk, W. J. Murdoch, D. M. Hallford, and G. E. Moss. 2004. Effects of feed restriction on reproductive and metabolic hormones in ewes. J. Anim. Sci. 82:2548-2557.

Kohn, R. A., M. M. Dinneen, and E. Russek-Cohen. 2005. Using blood urea nitrogen to predict nitrogen excretion and efficiency of nitrogen utilization in cattle, sheep, goats, horses, pigs, and rats. J. Anim. Sci. 83:879-889.

Lacetera, N., O. Franci, D. Scalia, U. Bernabucci, B. Ronchi, and A. Nardone. 2002. Effects of nonesterified fatty acids and beta-hydroxybutyrate on functions of mononuclear cells obtained from ewes. Am. J. Vet. Res. 63:414-418.

Latshaw, J. D. 1991. Nutrition - mechanisms of immnosuppression. Vet. Immunol. Immunopathol. 30:111-120.

Lochmiller, R. L., and C. Deerenberg. 2000. Trade-offs in evolutionary immunology: just what is the cost of immunity? Oikos 88:87-98.

MAFF. 1984. Energy allowances and feeding system of ruminants. Reference Book No. 433. Ministry of Agriculture, Fisheries and Food, Her Majesty's Stationary Office, London, UK.

Mahgoub, O., C. D. Lu, and R. J. Early. 2000. Effects of dietary energy density on feed intake, body weight gain and carcass chemical composition of Omani growing lambs. Small Rumin. Res. 37:35-42.

Meissner, H. H., H. H. Koster, S. H. Nieuwoudt, and R. J. Coertze. 1991. Effect of energy supplementation on intake and digestion of early and mid-season ryegrass and Panicum / Smuts finger hay, and on in sacco disappearance of various forage species. South Afr. J. Anim. Sci. 21:33-42.

Moyes, K. M., J. K. Drackley, J. L. Salak-Johnson, D. E. Morin, J. C. Hope, and J. J. Loor. 2009. Dietary-induced negative energy balance has minimal effects on innate immunity during a Streptococcus uberis mastitis challenge in dairy cows during mid lactation. J. Dairy Sci. 92:4301-4316.

Oetzel, G. R., L. L. Berger, W. E. Hoffman, D. F. Parrett, and A. J. Parker. 1988. Assessment of protein and energy status of ewes. Nutr. Repts. Intl. 37:1245-1254.

Ofay, J. M., and B. D. Rosenguist. 1988. Combined effects of fasting and diet on with a vaccine strain of infectious bovine rhinotrachitis virus. Am. J. Vet. Res. 49:1311-1315.

Olson, D. P., and R. C. Bull. 1986. Antibody responses in protein energy restricted beef cows and their cold stressed progeny. Can. J. Vet. Res. 50:410-417.

Ørskov, E. R., N. A. MacLeod, S. T. M. Fahmy, L. Istasse, and F. D. De B. Hovell. 1983. Investigation of nitrogen balance in dairy cows and steers nourished by intragastric infusion. Effect of sub-maintenance energy input with or without protein. Br. J. Nutr. 50:99-107.

Pattanaik, A. K., S. A. Khan, and T. K. Goswami. 2007. Influence of iodine on nutritional, metabolic and immunological response of goats fed Leucaena leucocephala leaf meal diet. J. Agric. Sci. Camb. 145:395-405.

Richterich, R. 1969. Clinical chemistry theory and practice. S. Karger, Basel, Switzerland. pp. 336-337.

Roach, T. I. A., C. H. Barton, D. Chatterjee, F. Y. Liew, and J. M. 
Blackwell. 1995. Opposing effects of interferon- $\gamma$ on iNOS and interleukin-10 expression in lipopolysaccharide- and mycobacterial lipoarabinomannan- stimulated macrophages. Immunol. 85:106-113.

Rodríguez, A. B., R. Bodas, N. Prieto, R. Landa, A. R. Mantecón, and F. J. Giráldez. 2008. Effect of sex and feeding system on feed intake, growth, and meat and carcass characteristics of fattening Assaf lambs. Livest. Sci. 116:118-125.

Ropstad, E., H. J. Larsen, and A. O. Refsdal. 1989. Immune function in dairy cows related to energy balance and metabolic status in early lactation. Acta Vet. Scand. 30:209-219.

Sahoo, A., A. K. Pattanaik, and T. K. Goswami. 2009. Immunobiochemical status of sheep exposed to periods of experimental protein deficit and re-alimentation. J. Anim. Sci. 87:2664-2673.

Salih-Alj Debbarh, H., A. Cloeckaert, G, Bézard, G. Dubray, and M. S. Zygmunt. 1996. Enzyme-linked immunosorbent assay with partially purified cytosoluble 28-kilodalton protein for serological differentiation between Brucella melitensisinfected and B. melitensis Rev.1-vaccinated sheep. Clin. Diagn. Lab. Immunol. 3:305-308.

Santra, A., and S. A. Karim. 1999. Effect of protein levels in creep mixture on nutrient utilization and growth performance of preweaner lambs. Small Rumin. Res. 33:131-136.

Scalia, D., N. Lacetera, U. Bernabucci, K. Demeyere, L. Duchateau, and C. Burvenich. 2006. In vitro effects of nonesterified fatty acids on bovine neutrophils oxidative burst and viability. J. Dairy Sci. 89:147-154.

Schalm, O. W., N. C. Jain, and E. J. Carol. 1975. Veterinary Haematology. 3rd edn, Lea and Febiger, Philadelphia, USA. p. 807.

Schrick, F. N., J. C. Spitzer, T. C. Jenkins, D. M. Henricks, and T. G. Althen. 1990. Effect of dietary energy restriction on metabolic and endocrine responses during the estrus cycle of the suckled beef cow. J. Anim. Sci. 68:3313-3321.

Schroeder, G. F., and E. C. Titgemeyer. 2008. Interaction between protein and energy supply on protein utilization in growing cattle: A review. Livest. Sci. 114:1-10.

Singh, K., G. Habib, M. M. Siddiqui, and M. N. M. Ibrahim. 1997. Dynamics of feed resources in mixed farming systems of South Asia. In: Crop Residues in Sustainable Mixed CropLivestock Farming System (Ed. C. Renold), p. 113. CAB International, Wallingford, UK.

Singh, V. K., A. K. Pattanaik, K. Sharma, and M. Saini. 2011. Effect of dietary energy intake on erythrocytic antioxidant defense in growing lambs fed a wheat straw-based diet. Anim. Prod. Sci. 51:642-649.

Snedecor, G. W., and W. G. Cochran. 1989. Statistical Methods. 9th edn. The Iowa State University Press, Ames, Iowa.
Sticker, L. S., D. L. Thompson Jr., J. M. Fernandez, L. D. Bunting, and C. L. DePew. 1995. Dietary protein and(or) energy restriction in mares: plasma growth hormone, IGF-I, prolactin, cortisol, and thyroid hormone responses to feeding, glucose, and epinephrine. J. Anim. Sci.73:1424-1432.

Suriyasathaporn, W., A. J. J. M. Daemen, E. N. NoordhuizenStassen, S. J. Dieleman, M. Nielen, and Y. H. Schukken. 1999. $\beta$-hydroxybutyrate levels in peripheral blood and ketone bodies supplemented in culture media affect the in vitro chemotaxis of bovine leukocytes. Vet. Immunol. Immunopathol. 68:177-186.

Trevisi, E., and G. Bertoni. 2009. Some physiological and biochemical methods for acute and chronic stress evaluation in dairy cows. Italian J. Anim. Sci. 8:265-286.

Tunn, S., H. Mollmann, J. Barth, H. Derendorf, and M. Krieg. 1992. Simultaneous measurement of cortisol in serum and saliva after different form of cortisol administration. Clin. Chem. 38:1491-1494.

Van Soest, P. J., J. B. Robertson, and B. A. Lewis. 1991. Methods of dietary fiber, neutral detergent fiber and non-starch polysaccharides in relation to animal nutrition. J. Dairy Sci. 74:3583-3597.

Waters, W. R., M. V. Palmer, R. E. Sacco, and D. L. Whipple. 2002. Nitric oxide production as an indication of Mycobacterium bovis infection in white-tailed deer (Odocoileus virginianus). J. Wildlife Dis. 38:338-343.

Wathes, D. C., Z. Cheng, W. Chowdhury, M. A. Fenwick, R. Fitzpatrick, D. G. Morris, J. Patton, and J. J. Murphy. 2009. Negative energy balance alters global gene expression and immune responses in the uterus of postpartum dairy cows. Physiol. Genomics 39:1-13.

Whitehair, C. K. 1958. Nutritional deficiencies. In: Diseases of Swine (Ed. H. W. Dunne) Iowa State University Press, Ames, IA, USA, pp. 627-648.

Woodward, L. F., W. P. Eckblad, D. P. Olson, R. C. Bull, and D. O. Everson. 1980. Effects of maternal protein-energy malnutrition on lymphoblastogenic responses of bovine neonates subjected to cold stress. Am. J. Vet. Res. 41:561-563.

Wynn, P. C., P. J. Reis, E. Fleck, W. Ward, D. A. Tunks, and S. G. Munro. 1988. The influence of protein and energy supply on ovine metabolic hormone status. Proc. Nutr. Soc. Aust. 13:125.

Yurtman, I. Y., T. Savas, F. Karaagac, and L. Coskuntuna. 2002. Effects of daily protein intake levels on the oral stereotypic behaviours in energy restricted lambs. Appl. Anim. Behav. Sci. 77:77-88

Zhao, B., M. T. Collins, and C. J. Czuprynski. 1997. Effects of gamma interferon and nitric oxide on the interaction of Mycobacterium avium sub species paratuberculosis with bovine monocytes. Infect. Immun. 65:1761-1766. 